\title{
PENERAPAN PENDEKATAN PEMBELAJARAN MATEMATIKA REALISTIK UNTUK MENINGKATKAN PEMAHAMAN MATEMATIS SISWA SD
}

\author{
Anggy Giri Prawiyogy \\ Fakultas Keguruan dan Ilmu Pendidikan \\ Universitas Buana Perjuangan Karawang \\ giriprawiyogi@gmail.com
}

\begin{abstract}
This research is motivated by low mathematical understanding of students on the subject of wake up space. The research was conducted in class IVA at one of SDN Ciseureuh, Purwakarta district. The approach used is realistic mathematics by using the media in the form of objects that have been often the students meet everyday. The type of research used is PTK with the aim to know the activity and improvement of students' mathematical understanding after the application of realistic mathematical approach. The result of research indicate that realistic mathematics learning approach can improve mathematical understanding of IVA class student, besides it can also increase student activity. Increased understanding of students in the cycle I $64 \%$ and $88 \%$ cycle II. The percentage of mathematical understanding of each indicator in the first cycle as much as $48.8 \%$ of students in the category understood entirely then in cycle II increased to $62.4 \%$. Based on the observation, student activity is increasing. By seeing the better improvement in each cycle it can be concluded that the realistic mathematics learning approach proved to improve students' mathematical understanding on the subject of building space in the class IVA at one of SDN Ciseureuh

Keywords: A Realistic Approach to Mathematics, Improving Mathematical Understanding
\end{abstract}

\begin{abstract}
Abstrak: Penelitian ini dilatarbelakangi oleh rendahnya pemahaman matematis siswa pada pokok bahasan bangun ruang. Penelitian dilakukan di kelas IVA pada salah satu SDN Ciseureuh, kabupaten Purwakarta Pendekatan yang digunakan adalah matematika realistik dengan menggunakan media berupa benda-benda yang sudah sering siswa jumpai sehari-hari. Jenis penelitian yang digunakan adalah PTK dengan tujuan untuk mengetahui aktivitas dan peningkatan pemahaman matematis siswa setelah diterapkannya pendekatan matematika realistik. Hasil penelitian menunjukkan bahwa pendekatan pembelajaran matematika realistik dapat meningkatkan pemahaman matematis siswa kelas IVA, disamping itu dapat pula meningkatkan aktivitas siswa. Peningkatan pemahaman siswa pada siklus I 64\% dan siklus II $88 \%$. Persentase pemahaman matematis tiap indikatornya pada siklus I sebanyak $48,8 \%$ siswa pada kategori paham seluruhnya kemudian di siklus II meningkat menjadi $62,4 \%$. Berdasarkan hasil observasi, terlihat aktivitas siswa semakin meningkat. Dengan melihat peningkatan yang semakin baik di setiap siklusnya maka dapat disimpulkan bahwa pendekatan pembelajaran matematika realistik terbukti dapat meningkatkan pemahaman matematis siswa pada pokok bahasan bangun ruang di kelas IVA pada salah satu SDN Ciseureuh.
\end{abstract}

Kata Kunci: Pendekatan Matematika Realistik, Meningkatkan Pemahaman Matematis 


\section{PENDAHULUAN}

Matematika merupakan salah satu mata pelajaran yang dipelajari oleh seluruh siswa mulai dari jenjang Sekolah Dasar (SD) hingga jenjang perguruan tinggi. Matematika diajarkan sejak SD sebab matematika memang melekat dengan kehidupan sehari-hari, bahkan sejak siswa belum masuk dunia sekolah. Adam \& Hamm (Wijaya, 2012, hlm. 5) menyebutkan manfaat matematika dalam kehidupan diantaranya ialah sebagai suatu cara untuk berfikir logis, kritis, analitis, sistematis, cermat, serta berguna dalam kehidupan sehari-hari. Cockroft (Sukamiyati, 2014, hlm 22) mengemukakan bahwa matematika perlu diajarkan kepada siswa karena matematika selalu digunakan dalam segala segi kehidupan dan juga semua bidang studi. Dalam setiap bidang studi tentunya diperlukan keterampilan matematika yang sesuai, matematika pun merupakan sarana komunikasi yang kuat, singkat dan jelas. Pada pelaksanaannya di lapangan sering dijumpai siswa yang kesulitan dalam memahami pelajaran matematika, sebagian dari para siswa beranggapan matematika membosankan bahkan menakutkan. Hal tersebut telah dibuktikan oleh survei dilakukan oleh Programme for International Student Assesment (PISA). PISA merupakan program penilaian skala internasional yang bertujuan untuk mengetahui sejauh mana siswa dapat menerapkan pengetahuan yang sudah mereka pelajari di sekolah. Hasil yang di peroleh pada survei yang di lakukan tahun 2009, Indonesia berada pada rangking 61 dari 65 negara yang turut serta dalam pelaksanaan survei tersebut (Wijaya, 2012: 1).

Untuk dapat meningkatkan kemampuan siswa pada mata pelajaran matematika maka siswa harus benar-benar memahami materi dasar sebelum mempelajari materi yang lebih kompleks. Pemahaman terhadap konsep matematika merupakan dasar untuk memahami matematika. Apabila siswa sudah paham maka siswa dapat menyelesaikan soal-soal yang lebih bervariasi dan mampu mengaplikasikannya ke kehidupan sehari-hari.

Berdasarkan hasil pengamatan dan diskusi dengan guru yang dilakukan di salah satu SDN Ciseureuh kelas IVA, diketahui bahwa siswa masih mengalami kesulitan dalam memahami materi pembelajaran matematika. Saat peneliti mengajukan pertanyaan dasar mengenai bangun ruang, hanya beberapa siswa yang dapat 
menjawab pertanyaan peneliti. Melalui studi pendahuluan pun diketahui pemahaman matematis siswa menganai bangun ruang masih rendah. Materi mengenai sifat-sifat bangun ruang hendaknya sudah dipahami oleh siswa di kelas IV sebab materi tersebut berkaitan dengan materi bangun ruang di kelas V dan juga di tingkat-tingkat selanjutnya. Apabila siswa sudah paham dengan materi dasar di kelas IV ini tentu akan memudahkan siswa untuk mengerjakan soal yang lebih variatif/kompleks di tingkat selanjutnya.

Kurangnya pemahaman siswa disebabkan oleh beberapa faktor, yang pertama kurangnya aktivitas yang membuat siswa semakin bersemangat ketika belajar matematika. Kedua, proses pembelajaran, khususnya bangun ruang belum bertolak dari lingkungan sekitar siswa, sehingga pembelajaran kurang bermakna. Sebagaimana dikatahui terdapat perbedaaan karakteristik antara siswa SD dan matematika, maka diperlukan model atau pendekatan pembelajaran yang sesuai dengan tahap berpikir siswa. Tahap berfikir siswa seperti yang dikemukakan oleh Bruner (Ningsih, 2014, hlm 89), terdapat tiga tahap yakni tahap enactive, iconic dan simbolic. Pada tahap enactive, siswa memanipulasi objek-objek secara langsung. Kemudian tahap iconic siswa mulai memahami, mencerna bentuk-bentuk perumpamaan. Selanjutnya pada tahap simbolic siswa memanipulasi simbol-simbol secara langsung dan sudah tidak ada kaitannya dengan objek.

Salah satu pendekatan yang menekankan pada aktivitas siswa, bertolak dari kehidupan sehari-hari dan juga sesuai dengan tahap berfikir Bruner ialah pendekatan Realistic Mathematic Education atau dikenal pula sebagai Pendekatan Matematika Realistik (PMR). Zulkardi (Junaidi, 2011) menjelaskan bahwa: Pendekatan Matematika Realistik adalah pendekatan dalam pendidikan matematika yang berdasarkan ide bahwa matematika adalah aktivitas manusia dan matematika harus dihubungkan secara nyata dalam konteks kehidupan sehari-hari peserta didik sebagai suatu sumber pengembangan sekaligus sebagai aplikasi melalui proses matamatisasi baik secara vertikal maupun horizontal.

Pada pendekatan pembelajaran matematika realistik, pendidik berperan sebagai fasilitator, moderator dan evaluator. Sementara siswa berfikir, mengkomunikasikan dan melatih nuansa demokratif dengan menghargai pendapat orang lain (Ningsih, 
2014, hlm 77). Pendekatan pembelajaran matematika realistik ini sesuai dengan namanya bertolak dari hal-hal yang real atau hal-hal sekitar siswa sehingga pembelajaran tidak dirasa terpisah dengan kehidupan siswa. Pada proses pembelajarannya pun menekankan pada keterampilan proses yakni siswa melakukan diskusi dan kolaborasi dengan teman sekelas sehingga siswa menemukan sendiri suatu konsep dan cara menyelesaikan masalah. dengan adanya kegiatan tersebut diharapkan siswa akan lebih paham dan memaknai materi materi ajar matematika. Lebih khususnya, pendekatan pembelajaran matematika realistik yang telah dikembangkan selama kurang lebih 30 tahun menunjukkan hasil yang baik. Pendekatan ini juga dikembangkan di beberapa negara lain seperti USA (yang dikenal dengan Mathematics in Context), Afrika Selatan, Malaysia, Inggris, Brazil, dan lain-lain (Benu, 2000).

\section{METODE PENELITIAN}

Penelitian yang dilakukan adalah Penelitian Tindakan Kelas (PTK). Kemmis dan Mc. Taggart (1988): PTK adalah studi yang dilakukan untuk memperbaiki diri sendiri, pengalaman kerja sendiri yang dilaksanakan secara sistematis, terencana, dan dengan sikap mawas. Jadi Penelitian tindakan kelas merupakan terjemahan dari Classroom Research, yaitu satu action research yang dilakukan oleh guru di dalam kelasnya sendiri melalui refleksi diri, dengan tujuan untuk memperbaiki kinerjanya sebagai guru, sehingga hasil belajar siswa menjadi menjadi meningkat.

Jenis penelitian yang digunakan yaitu penelitian tindakan kelas partisipan. Bentuk penelitian yang digunakan yaitu penelitian tindakan kolaboratif. Sedangkan model yang akan digunakan yaitu Model Kemmis dan Tagart. Hal ini dikarenakan dalam satu siklus terdapat satu tindakan, yaitu penerapan model pembelajaran multiliterasi dengan menggunakan pendekatan matematika ralistik. Model ini terdiri dari tahap perencaaan, tahapan pelaksanaan, tahap observasi dan tahap refleksi.

Partisipan dalam penelitian ini dipilih menggunakan sampling purposif. Sudjana (2005, hlm. 168) mengemukaan bahwa "Sampling purposif dikenal juga 
sebagai sampling pertimbangan, terjadi apabila pengambilan sampel dilakukan berdasarkan pertimbangan perorangan atau pertimbangan peneliti”.

Penelitian tindakan kelas ini dilaksanaan di salah satu SD yang berlokasi di Provinsi Jawa Barat, Kabupaten Purwakarta, Kecamatan Purwakarta. Penelitian ini dilakukan selama 1 hari untuk setiap siklusnya, dengan selang waktu satu minggu antara siklus I ke siklus II.

Instrumen yang digunakan yaitu (1)intrumen pengungkap data kualitatif digunakan untuk memperoleh data berupa aktivitas guru dan siswa yang menunjukan efektivitas model pembelajaran matematika dengan menggunakan pendekatan matematika realistik yang diukur dengan menggunakan lembar observasi terstruktur dan lembar observasi terbuka serta catatan lapagan, (2)instrumen pengungkap data kuantitatif digunakan untuk memperoleh data kemampuan pemahaman matematis dalam bentuk skor yang diperoleh menggunakan instrumen tes, wawancara dan observasi.

Analisis data yang digunakan dalam penelitian ini yaitu analisis data kuantitatif digunakan untuk menganalis data kemampuan pemahaman matematis siswa dan analisis data kualitatif yang digunakan untuk menganalisis data lembar observasi dan catatan lapangan, yang dianalisis menggunakan teknik analisis interaktif yang dikembangkan oleh Miles dan Huberman. Adapun dalam hal ini peneliti melakukan analisis data seperti berikut:

1. Analisis data secara kualitatif

Analisis data secara kualitatif dilakukan terhadap pemerolehan data melalui lembar observasi, dokumentasi, dan wawancara. Hasil dari ketiga instrumen penelitian ini bersifat naratif deskriptif sehingga data disajikan dalam bentuk kualitatif

2. Analisis data secara kuantitatif

Analisis data secara kuantitatif dilakukan terhadap hasil tes yang dilakukan secara individual terhadap kemampuan pemahaman matematis siswa dalam pembelajaran matematika dan analisis data hasil observasi aktivitas siswa. 


\section{HASIL DAN PEMBAHASAN}

Secara keseluruhan pembelajaran di setiap siklus sesuai dengan rencana yang telah ditetapkan. Meskipun terdapat kekurangan di setiap pertemuan, tetapi proses pembelajaran dapat terlaksana dengan baik. Seperti pada fokus penelitian yang ada dalam rumusan masalah maka penelitian ini dilakukan untuk mengetahui aktivitas siswa selama pembelajaran dengan menerapkan pendekatan matematika realistik dan bagaimana pemahaman matematis siswa setelah diterapkannya pendekatan matematika realistik.

\section{Aktivitas Siswa}

Selama proses pembelajaran dengan menerapkan pendekatan matematika realistik dalam pokok bahasan bangun ruang menunjukkan aktivitas siswa yang semakin aktif dan mengalami peningkatan di setiap siklusnya. Pada siklus I persentase aktivitas siswa adalah 57,5\% termasuk dalam kriteria cukup. Saat pelaksanaan pembelajaran masih terdapat siswa yang tidak mau turut serta dalam diskusi kelompok, meskipun sudah peneliti tegur namun tak lama kemudian siswa kembali lagi pada aktivitasnya. Sehingga hanya satu atau dua orang saja yang mendominasi jalannya diskusi kelompok. Pada siklus II dengan adanya arahan dan motivasi terus menerus siswa pun akhirnya mau turut serta dalam kelompok. Hal ini sejalan dengan yang di kemukakan oleh Unno (Susanti, 2013, hlm 4) bahwa motivasi merupakan faktor penting dalam keberhasilan belajar dan pembelajaran.

Selain mengobservasi siswa, observasi juga dilakukan terhadap aktivitas peneliti selama mengajar, hal tersebut untuk memastikan bahwa semua aspek yang harus muncul selama menerapkan pendekatan matematika realistik terlaksana serta dapat digunakan sebagai refleksi peneliti selama setelah melakukan pembelajaran. Observasi dilakukan oleh wali kelas agar penilaian lebih bersifat objektif. Berikut data yang diperoleh dari siklus I hingga siklus II

\section{Pemahaman Matematis}

Dengan diterapkannya pendekatan matematika realistik, ternyata memberikan dampak yang positif bagi peningkatan pemahaman matematis siswa dalam pembelajaran. Peningkatan hasil tes pemahaman matematis siswa baik secara individu maupun klasikal tidak terlepas dari meningkatnya aktivitas siswa selama 
proses pembelajaran. Hal ini sejalan dengan teori belajar Vygotsky yang menekankan pada hakekat sosiokultural (Sugeng, 2004, hlm 28). Menurut Vygotsky dengan adanya interaksi antara siswa dengan siswa atau siswa dengan orang dewasa, maka pengetahuan siswa akan semakin meningkat sebab adanya pertukaran informasi dan bantuan selama interaksi tersebut.

Terbukti dari hasil tes pemahaman siklus I yang memenuhi syarat KKM sebanyak 16 siswa atau 64\% dengan nilai rata-rata 72. Pada siklus II mengalami peningkatan, siswa yang mencapai KKM menjadi berjumlah 22 siswa atau $88 \%$ dengan nilai rata-rata 84,52 . Melihat hasil yang semakin meningkat disetiap siklusnya maka dapat disimpulkan bahwa penelitian tindakan kelas tentang penerapan pendekatan matematika realistik untuk meningkatkan pemahaman matematis siswa kelas IVA dinyatakan berhasil.

\section{PENUTUP}

Selama pelaksanaan penelitian, aktivitas siswa khususnya pada saat pelaksanaan diskusi kelompok sudah mengalami peningkatan yang signifikan dari pelaksanaan siklus I hingga pelaksanaan siklus II. Aspek-aspek aktivitas siswa yang diamati telah dilaksanakan dengan baik oleh siswa. Pada pelaksanaan siklus I semua aspek belum terlaksana dengan baik, situasi kelas pun masih terbilang tidak kondusif hal tersebut dikarenakan siswa yang belum terbiasa dengan situasi diskusi kelompok dan soal-soal pemahaman yang diberikan. Namun setelah dilakukan pendekatan dan juga tindakan perbaikan pada siklus II, aktivitas siswa telah sesuai dengan yang diharapkan. Siswa sudah dapat menggunakan masalah sehari-hari dalam pembelajaran bangun ruang, siswa juga sudah mampu melakukan diskusi kelompok dan tidak malu-malu lagi mengajukan ide/pendapatnya.

Hal lainnya adalah yang berkaitan dengan peningkatan pemahaman matematis siswa. Pemahaman matematis siswa pada awalnya masih tergolong kurang. Pada pelaksanaan siklus I, nilai yang diperoleh siswa dari tes pemahaman belum mencapai standart yang ditentukan. Secara klasikal ketuntasan siswa baru $64 \%$. Namun melalui pelaksanaan tindakan perbaikan pada siklus II sudah terlihat 
peningkatannya, siswa sudah mencapai ketuntasan klasikal yang ideal yakni $88 \%$, pemahaman matematisnya pun umumnya sudah pada kategori sangat baik.

\section{DAFTAR RUJUKAN}

Adjie, N. d. (2007). Pemecahan Masalah Matematika. Bandung: UPI Press.

Arikunto, S. (1996). Prosedur Penelitian. Jakarta: PT Rineka Cipta.

Astuti, P. (2014). Penggunaan Media Benda Konkret Untuk Meningkatkan Hasil Belajar Siswa. Jurnal UIN Vol I, 25-36.

Benu, S. (2000). Mengajar MAtematika Dengan Pendekatan Realistik. Retrieved from http://zahra-abcd.blogspot.com

Burhanuddin, T. (2012). Model, Metode, dan Teknik Penelitian Pendidikan. Purwakarta: UPI.

Cahye. (2008). Upaya Meningkatkan Prestasi Belajar Matematika Siswa Melalui Model Pembelajaran Tutor Sebaya. Skripsi UPI Bandung: Tidak

Diterbitkan.

Graha, A. T. (2013). Pengaruh Pendekatan Matematika Realistik Terhadap Pemecahan Konsep Matematika Siswa. Pedagogy Vol II, 1-10.

Hartono. (2011). Metodologi Penelitian. Pekanbaru: Zanafa Publishing.

Hermawan, A, dkk. (2007). Belajar dan pembelajaran sekolah dasar. Bandung: UPI Press.

Junaidi, W. (2011). Pendekatan Matematika Realistik. Retrieved from http://wawan-junaidi.blogspot.com/2011/03/pendekatanmatematikarealistik.html

Kasbolah, K. (1998). Penelitian Tindakan Kelas. Jakarta: Depdikbud.

Kusumah, W \& Dwitagama, D. (2012). Mengenal Penelitian Tindakan Kelas. Jakarta: PT. Indeks.

Misel. (2015). Penerapan Pendekatan Matematika Realistik untuk Meningkatkan Kemampuan Representasi Matematis Siswa. Purwakarta: UPI Tidak Diterbitkan.

Mulyani, S \& Syaodih, N . (2006). Perkembangan Peserta Didik. Jakarta: Universitas Terbuka.

Ningsih, S. (2014). Realistic Mathematics Education: Model Alternatif Pembelajaran Matematika Sekolah. JPM IAIN Antasari Vol. 01 No. 2, 7394.

Sugeng, M. (2004). Pengaruh Pembelajaran Realistik Terhadap Prestasi Belajar Matemalika Unit Geometri pada Siswa Kelas III IPA SMU. Surakarta: Pasca Sarjana UNS. 
Sukamiyati. (2014). Meningkatkan Hasil Belajar Matematika Melalui Pendidikan Matematika Realistik (PMR) Pada Siswa Kelas IV SDN Timbulharjo. Jurnal UNY Vol II, 21-27.

Surya, M. (2004). Psikologi Pembelajaran dan Pengajaran. Bandung: Pustaka Bani Quraisy.

Susanti, Y. (2013). Pengaruh Aktivitas Dan Motivasi Belajar Terhadap Hasil Belajar Dalam Pembelajaran Ekonomi Siswa Kelas X. Jurnal UNP Vol 1 No $1,50-62$.

Susanto. (2013). Teori Belajar dan Pembelajaran. Jakarta: Prenada Media Grup.

Suwaningsih, E dan Tiurlina. (2006). Model Pembelajaran Matematika. Bandung: UPI Press.

Trianto. (2007). Model-model Pembelajaran Inovatif Berorientasi Konstruktivistik. Jakarta: Prestasi Pustaka.

Trianto. (2012). Panduan Lengkap Penelitian Tindakan Kelas. Jakarta: Prestasi Putakarya.

Wijaya, A. (2012). Pendidikan Matematika Realistik. Yogyakarta: Graha Ilmu.

Yawisah, U. (2013). Reciprocal Teaching: One Of The Methods For Poor Comprehenders. Pedagogy Vol I, 22. 